\title{
obituary
}

\section{Maurice Ingram}

Dr Maurice Ingram, former Director of the Agricultural Research Council Meat Research Institute at Langford and Professor of Applied Microbiology at the University of Bristol from 1968 to 1973 , died suddenly at his home in Churchill, Avon, on Tuesday 15 November 1977.

Dr Ingram, who was born in Bradford in 1912, was educated at Bradford Grammar School and had a distinguished undergraduate career at Queens' College, Cambridge. After an early interest in botany he became increasingly concerned with food microbiology. His Ph.D. dissertation on The Effect of Salts in Bacterial Respiration was presented after joining the Low Temperature Station for Research in Biochemistry and Biophysics where he became Head of the Microbiology Department in 1951.

His early research on bacterial growth and metabolism led to studies of the involvement of pre- and postslaughter stress factors in the quality and stability of cured products. This work became particularly significant during the second world war when he was engaged in problems of transporting meat and with its salvage after enemy action. In addition he directed research that led to the development of the special rations issued to Allied invading armies and to underground organisations in Europe. He later received the Haakon VII Liberty Medal from the Norwegian Government for his contribution to the partisan attack which destroyed the heavy water plant at Rjukan.

From 1947-49 he studied the bacteriology of whalemeat in an effort to utilise this wasted source of protein. $\mathrm{His}$ work on the preservation of concentrated orange juice, which involved travelling to Israel, Italy and Spain, led to the elimination of serious losses. Subsequently he led a team investigating the preservation of foods by ionising radiation. His earlier work again became imprtant in further studies of curing, particularly with reference to food safety and the control of Clostridium botulinum by curing salts. He was also active in developing microbial specifications for foods.

In $1963 \mathrm{Dr}$ Ingram was appointed the first Director of the projected Meat Research Institute and as he also became Director of the Low Temperature Station in 1965 he was involved in the planning and recruitment for the two Institutes which replaced it, the Food Research Institute at Norwich and the Meat Research Institute at Langford. The latter was opened by H.M. the Queen in 1968 and Dr Ingram remained Director until 1973; an honorary degree of Doctor of Veterinary Medicine being conferred on him by the Ludwig-Maximilians University of Munich that year followed by the CBE in 1974 .

$\mathrm{He}$ retired earlier than necessary to avoid ever-increasing administration which he did not enjoy. Retirement meant that he was able to devote himself more fully to science, and his international reputation ensured that he continued to travel widely, both in a personal capacity and as a consultant for the World Health Organisation. In July 1977 he received the Polish Society of Microbiology Gold Medal of Honour for "most outstanding services to microbiology"- a fitting tribute to a scientist of distinction and a man of great personal achievement.

A man of wide interests and ability he was an accomplished pianist, a keen botanist and, until recently, an enthusiastic and capable cricketer. $\mathrm{He}$ spoke French, German and some Norwegian, and read easily in those languages and in Danish. His colleagues will remember him as a man of great integrity, with a mind able to reduce complex questions to simplicity and to answer from a thorough understanding of the basic chemical and physical principles involved. His ability to evaluate arguments logically and to summarise complex discussions concisely made him especially valuable as a chairman at committees.

T. A. Roberts

\section{William Bullerwell}

Dr William Bullerwell, Frs, Frse, Deputy Director of the Institute of Geological Sciences, and Chief Geophysicist 1962-1977, died on 25 November aged 61

After graduating with first class honours in physics in 1937 from Durham University (King's College) he took a further degree in geology, gaining the Lebour Prize for Field Geology, and began research in mining geophysics. This was interrupted by war service during which he worked on experimental radar, and was mentioned in dispatches.

In the post-war period he joined the Geological Survey of Great Britain, now within the Natural Environment Research Council as part of the Institute of Geological Sciences. Following the pioneer geophysical work for the Survey by J. Phemister and W. F. P. McLintock, he initiated the programme of geophysics that is now a major part of the Institute's work.

In 1950 the Geophysics Division became reponsible for collating all gravity data obtained in Great Britain and for its final publication as maps of Bouguer Anomaly: eight quarterinch to one mile gravity overlay maps were published between 1954 and 1968. During the decade 1955-1965 he supervised the complete regional aeromagnetic survey of the United Kingdom which was published (following interim 1:250,000 scale Diagram Edition sheets) as colour-layered 'tenmile' aeromagnetic sheets in 1965 and 1972. With his wife, Eileen, whom he married in 1942, and Dr and Mrs James Phemister, during summer vacations from 1953-1956 he carried out the first reconnaissance gravity survey of Scotland

With the coming of the hydrocarbon search he became deeply involved in the government's research programme of hydrocarbon assessment and search on the continental shelf, especially in advising the Department of Energy. Recently he served on the Advisory Committee of Programme Management for Geothermal Energy of the Commission of European Communities, and from 1970 onwards he was much concerned with offshore prospecting in East Asia as representative for the Ministry of Overseas Development at the Economic and Social Commission for Asia and the Pacific Co-ordinating Committee.

Dr Bullerwell was an exceptionally kindly and generous man who had an encyclopaedic geophysical knowledge that was widely consulted and recognised, and he was elected FRS in 1972 (Council 1974-5) and FRSE in 1973. He served on numerous governmental, university and other professional committees, acting as Treasurer of the Geological Society from 1963-71, and as Chairman of the University of London's Advisory Board on Geophysics.

P. A. Sabine 